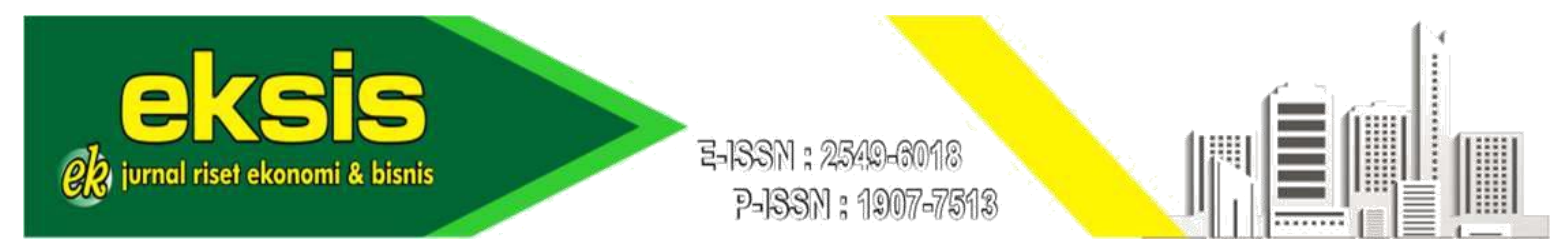

\title{
Green Investment: Incorporate Environment, Social, And Government Factors In Investment Decision
}

\author{
*Pandu Adi Cakranegara, Filson Maratur Sidjabat \\ Universitas Presiden \\ Correspondence: cakranegara@gmail.com
}

Submitted: 5 February 2021, Revised: 20 April 2021, Published: 5 May 2021

\begin{abstract}
:
There are two types of investors, the first is the type of investor who focuses on return on investment and the second type is the investor who pays attention to Environmental, Social, and Governance (ESG) values in investing. This requires management to make adjustments to create a competitive advantage. One of the frameworks used to measure the competitive advantage of a company is the Porter framework. However, Porter's framework needs to be supplemented with ESG values to capture the value creation process in today's business environment. This research is applied research by applying the existing framework in the field. In this case, the framework used consists of two, namely the Porter framework and the LST integration framework. The ESG framework is implemented at the industrial level using industrial divisions based on industrial divisions in the Indonesia Stock Exchange. This study focused on the raw material production sector, namely agriculture, and mining. This study showed that ESG factors affected the competitive advantage of companies and industries. If a company in an industry ignores the value of ESG, the company will experience a decrease in competitiveness. Meanwhile, if the industry does not pay attention to the ESG factor, the industry will experience a decline compared to other industries that pay attention to the ESG factor.

Keywords: Environmental Social Governance, Green Investment, Porter Five Forces, Valuation
\end{abstract}

\section{A. INTRODUCTION}

Investment is considered as a present sacrifice to obtain a future outcome (Tandelilin, 2001). This point of view combines the two basic elements of investing, namely risk and return. These elements show how much risk an investor is willing or able to take to get the appropriate rate of return. Focusing on reciprocal pursuit poses several problems, such as a pursuit of profit without regard to the sustainability of the company, the environment, and the social factors in which the company operates. Therefore, the investment can not only rely on one criterion but also need to have some additional criteria, to ensure that the return on investment (ROI) will be an investment that is good for the company today and also in the future, both for the company and the environment, where the company operates.

Investors invest in a company so that the company can run its business. But the company does not run its business in a vacuum but in an influential social, cultural, and natural environment. These things make the company need to manage so that these factors can support the sustainability of the company. Schramade (2016) adds Environmental Social and Governance (ESG) risk factors in a company's valuation. ESG risk comes from the company's physical environment, the social environment that can come from the community around the company, perceptions about the company, consumers and company employees, and corporate governance. For example, in Indonesia's context, which is geographically located in an active mountainous route, in terms of environmental factors, companies need to be prepared for various possible 
natural disasters. Foreign companies operating in Indonesia will bring a culture and work procedures from their home country that can be perceived negatively by the local community. Meanwhile, the risk of governance is when companies, especially foreign companies with branch office status, have the autonomy to make decisions but, on the other hand, have weak supervision from the head office.

Every company has value drivers and these value drivers have ESG risk. When the value driver of a company is related to environmental factors then the disruption of environmental factors will cause a direct decrease in company value. This risk needs to be adjusted for the company. Companies that pay attention to these risk factors mean better-prepared companies. Companies that do not pay attention to this factor are becoming more vulnerable.

One example of the company value disruption is what happened to the largest paper manufacturer in Indonesia, namely Asian Pulp and Paper (APP). When APP is considered to be destroying forests in the process of obtaining raw materials for paper making, then one of the big buyers of APP, Walt Disney America urged the American government to ban products from APP from entering the United States. This is a hard blow for APP and forces other companies to pay attention more to this issue on its supply chain, especially from the raw material side (Dawson, 2020).

What happened to the APP is an actual and extraordinary event that rarely happened. However, when the incident occurs, the impact is greater on the company's value and its sustainability. Such an event like this is common called the Black Swan phenomenon. The term Black Swan is a term popularized by Nassim Taleb to describe a phenomenon that has a very small probability of occurring but, when it occurs, will have a tremendous economic impact (Taleb, 2011). One example of Black Swan is a pandemic that is likely to occur very rarely. Even the last international pandemic occurred more than a hundred years ago. Nevertheless, when a pandemic occurs, and there are closures and restrictions on the movement of people, the economic impact is tremendous. In the world of finance, one of the steps that can be taken to overcome the Black Swan phenomenon is by hedging one of the examples is insurance. To be able to hedge or protect company value, the first thing that company management needs to do is identify risk factors - related to the company (Briand et al., 2011). In the financial world, these kinds of phenomena are trying to hedge. .Briand et al (2011) stated that long-term investment is not only a matter of opportunities that may occur in the future but also risks that may occur in the future. One of the risks that can cause the Black Swan phenomenon is the risk of ESG. So companies that do not pay attention to ESG risk, in the long run, will be prone to risks that can drop their value and interfere with its sustainability. On the investor side, companies must be adjusted to their valuation with the potential ESG risk borne by the company (Schramade, 2016). This study examines how ESG factors affect firm value at the industry level. Thus, it can be known which industry is more at risk of being affected by ESG factors and how much ESG risk affects it. The output of this study is a descriptive qualitative analysis of ESG risk in the Agribusiness and Mining sector. This study tries to connect environmental, social, and governance factors with company value. The framework used to connect the ESG factor with firm value is Porter's framework. Porter's framework helps assess a company's competitive advantage associated with the competitive conditions. So Porter's framework will bridge the value of ESG with the company's competitive advantage. The industries chosen in this study were the mining and agricultural industries. The choice of these two industries is because these two commodities are Indonesia's two leading 
commodities. This research's output is the application of Porter's framework, which adds environmental, social, and governance factors to the agricultural and mining industries in Indonesia. It is hoped that the results of this study will find a relationship between ESG factors and company value, so that company management can manage ESG factors to maintain company value.

\section{B. LITERATURE REVIEW}

In the evaluation of the main thing that gives rise to the value is called the value driver (Bohnert et al, 2019). Porter was one of the first economists to use economics and combined it with management science to recognize the value drivers of each company. Therefore, this value driver identification system was later known as Porter five forces. The Porter Five Forces diagram is primarily divided into five major sections consisting of interactions between buyers, sellers, and suppliers of sellers. The bargain of the buyer is influenced by the availability of alternative products, the existing competition between the sellers, the seller's ability for new, and the type of buyer. Meanwhile, the seller's ability to sell or produce is influenced by the supplier of its raw materials.

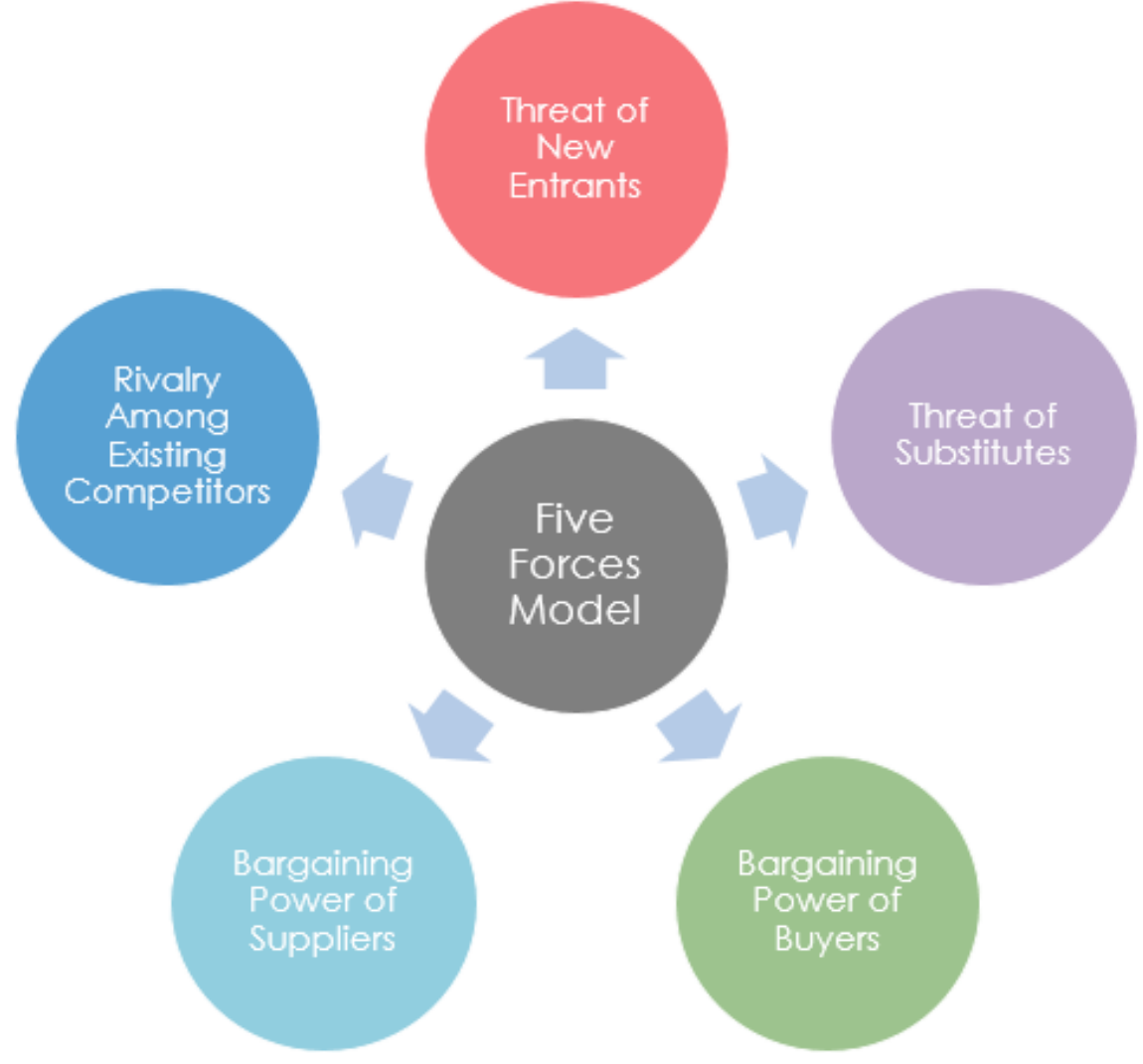

Figure 1: Porter Five Forces (Porter, 2008)

The variables in the Porter Five Forces can be broken down into various dimensions. From these dimensions can be seen the strength and interaction of each variable. From the sum of all these things, it is finally possible to know how the company creates value and how the company can maintain its position in the market. With these dimensions, companies that look similar but have different industries if viewed in more detail then in fact can be very different. 
Table 1. Dimension in each Porter Five Forces Variables

\begin{tabular}{|c|c|c|c|c|}
\hline $\begin{array}{l}\text { Rivalry } \\
\text { Among } \\
\text { Existing } \\
\text { Competitors }\end{array}$ & $\begin{array}{l}\text { Bargaining } \\
\text { Power } \\
\text { Suppliers }\end{array}$ & $\begin{array}{l}\text { The Threat of } \\
\text { Substitute } \\
\text { Products }\end{array}$ & $\begin{array}{l}\text { Bargaining } \\
\text { Power } \\
\text { Buyers }\end{array}$ & $\begin{array}{l}\text { The threat of } \\
\text { New Entrants }\end{array}$ \\
\hline $\begin{array}{l}\text { Number of } \\
\text { competitors } \\
\text { Diversity of } \\
\text { competitors } \\
\text { Industry } \\
\text { concentration } \\
\text { Industry } \\
\text { growth } \\
\text { Quality } \\
\text { differences } \\
\text { Brand loyalty } \\
\text { Barriers to exit } \\
\text { Switching cost }\end{array}$ & $\begin{array}{l}\text { Number and } \\
\text { size of } \\
\text { suppliers } \\
\text { The uniqueness } \\
\text { of } \\
\text { suppliers } \\
\text { product } \\
\text { Focal company } \\
\text { ability to } \\
\text { substitute }\end{array}$ & $\begin{array}{l}\text { Number of } \\
\text { substitute } \\
\text { products } \\
\text { available } \\
\text { Buyer } \\
\text { propensity to } \\
\text { substitute } \\
\text { The relative } \\
\text { price performance of } \\
\text { perfor } \\
\text { substitute } \\
\text { Perceived level } \\
\text { of product } \\
\text { differentiation } \\
\text { Switching cost }\end{array}$ & $\begin{array}{l}\text { Number of } \\
\text { customers } \\
\text { Size of each } \\
\text { customer order } \\
\text { Difference } \\
\text { between } \\
\text { competitors } \\
\text { Price } \\
\text { sensitivity } \\
\text { Buyer's ability } \\
\text { to substitute } \\
\text { Buyer's } \\
\text { information } \\
\text { availability } \\
\text { Switching cost }\end{array}$ & $\begin{array}{l}\text { Barriers to } \\
\text { entry } \\
\text { Economies of } \\
\text { scale } \\
\text { Brand loyalty } \\
\text { Capital } \\
\text { requirements } \\
\text { Cumulative } \\
\text { experiences } \\
\text { Government } \\
\text { policies } \\
\text { Access } \\
\text { distribution } \\
\text { channels } \\
\text { Switching cost }\end{array}$ \\
\hline
\end{tabular}

Source: Porter ,2008

ESG is a value dimension, but as a value dimension, the ESG factor has a discrepancy with the financial side of the company. The idea of making the interests of shareholders the main benchmark for the goals of the company causes the tendency of companies to pursue financial performance more. Giovanni et al. (2021) stated that the classic perception of conflict theory between investors and management is still management's grip in managing the company. Even though in the modern era, it is not enough to look into one perspective, but company management needs to look at multiple perspectives (Freudenreich et al., 2020). These deductions can be seen in diagram 2. Currently, in making financial decisions the company can no longer ignore the value dimensions that will influence the financial decisions. Companies do not operate in a static environment but a dynamic and human-involved environment. When talking about human beings then some values exist in the human self. This is what is trying to be captured in the values dimension.

Damodaran (2016) stated that the goal of a company is to create value. . Freudenreich et al. (2020) stated that the perspective of value creation for investors is not enough. The ideal is the creation of value for all parties' benefit, or in other words, not limited to stockholders but stakeholders. Tahu (2019) states that its environmental responsibility factor has a significant effect on its financial performance. The creation of value is measured by how many goods or services the company offers are received by the consumer until the purchase of the goods and services in the currency unit. The value of the company is the value of the financing of the total value of the cash flow generated by the company.

Palepu (2013) argues that while having value a company is inseparable from its environment. This finding is consistent with the findings of Tahu (2019), which found that concern for the company environment has a significant positive effect on company performance. Furthermore, to create the sustainability of corporate value, Freudenreich et al. (2020) stated that companies need to maintain environmental sustainability, mainly where they operate. The corporate environment starts from the international environment, the economic environment, and the competitive environment. The 
interaction between the company and this environment determines the potential of the company. Under the conditions of a free international environment, a stable and stable macroeconomic environment will create optimal value.

Penman (2016) then links between the risks borne by companies and value creation. Palepu (2013) states that company value cannot be separated from the business environment in which the company operates. Subramanyam (2014) defines a company's business environment as a macroeconomic environment and an industrial environment. Both of these environments are external environments that affect the value of the company. Company evaluation is based on how the company creates value in future years. The creation of this value path-dependent means that each value created will be the foundation for the subsequent value creation. Therefore the risks present in each phase of creation will affect the value in the next phase. By managing the risk in each phase then the company is ensuring that value is being created in each phase.

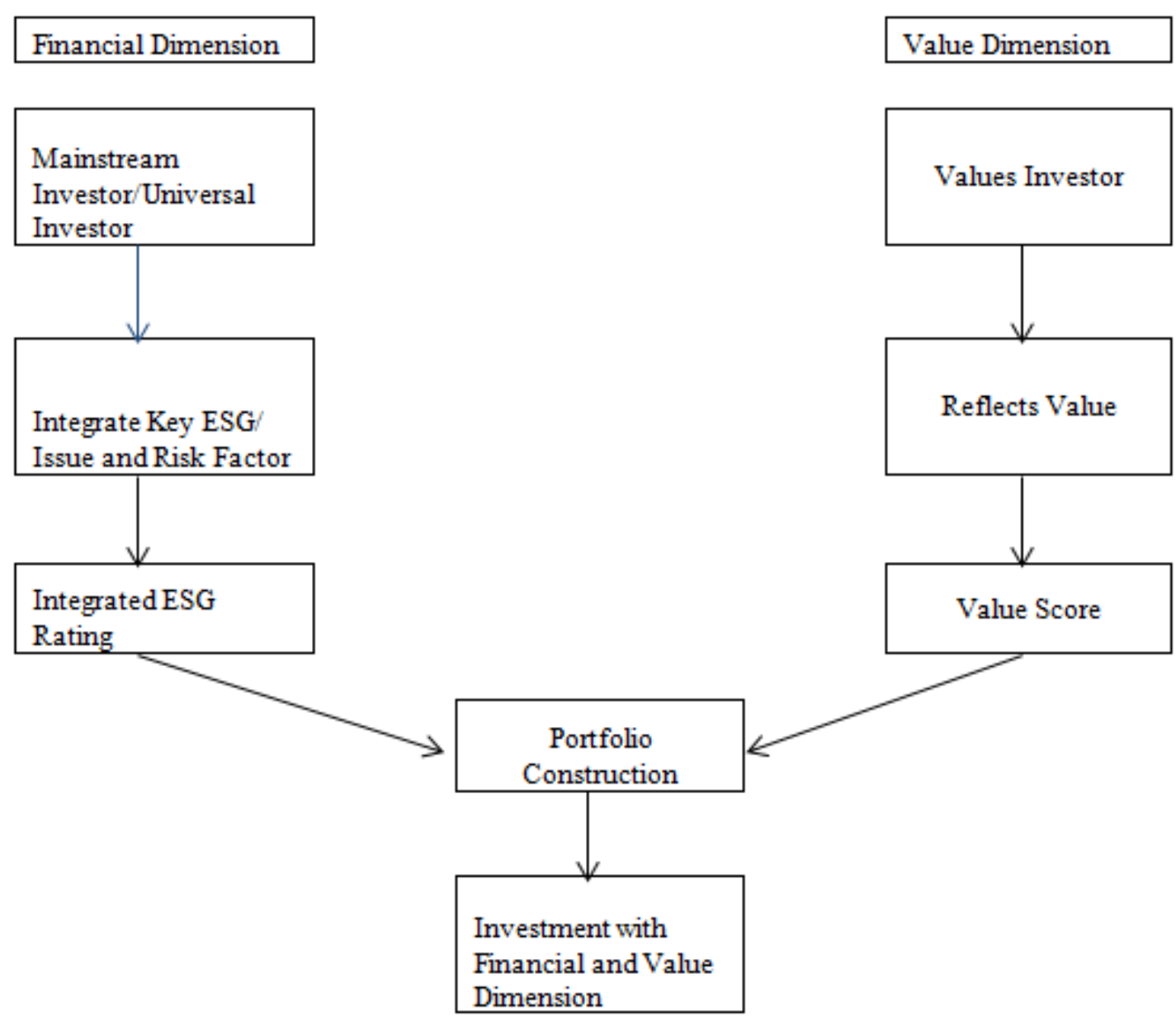

Figure 2: The intersection between the Financial Dimension and the Values Dimension Holland, 2011

From figure 2, it is seen that there are two types of investors. The first investor is a general investor who pays attention only to financial factors and the second type of investor is an investor who has certain values in investing. Although the two appear to be separate and start from a different starting point, it appears that in the process of 
making investment decisions there are cuts. At the moment these two investors are ultimately inseparable. This is because although universal investors are only pursuing reciprocity when a company is affected by the ESG factor, it does not want investors to be affected as well. In the end, all companies need to pay attention to the ESG factor because all companies are affected by the ESG factor.

\section{RESEARCH METHODS}

This research is applicative research by applying the existing framework in the field. In this case, the framework used consists of two, namely the Porter framework and the ESG integration framework. The implementation of this framework is done at the industry level (Yeoman, 2017). By applying this framework, it can be known which industry is more vulnerable to the impact of ESG factors.

Applicative research is useful for bridging the gap between theory and practice. The framework that has been created can then be applied and analyzed. Through the implementation process then it can be known a few things, among others, whether the framework is appropriate and whether the existing framework performs the function following the expected.

The implementation of the ESG framework is done at the industry level. Thus the results of this application will be able to know which industry is riskier and which industry is more prepared for the ESG factor. Industrial division by using industrial division based on the industrial division of the Indonesian Stock Exchange.

Based on the classification of industries in the Indonesian Stock Exchange, the industry in Indonesia is divided into 9 (nine), namely agriculture, mining, basic and chemical industries, various industries, consumer goods industry, real estate and building construction, infrastructure, utilities and transportation, finance, trade, services and investment (Sembiring, 2012).

\begin{tabular}{|c|c|c|c|c|}
\hline $\begin{array}{c}1 \\
\text { Agriculture }\end{array}$ & $\begin{array}{c}2 \\
\text { Mining }\end{array}$ & \multicolumn{3}{|c|}{ A. producer of raw materials } \\
\hline $\begin{array}{c}3 \\
\text { Basic industries } \\
\text { and chemical } \\
\end{array}$ & $\begin{array}{c}4 \\
\text { various } \\
\text { industries } \\
\end{array}$ & $\begin{array}{c}5 \\
\begin{array}{c}\text { consumer goods } \\
\text { industry }\end{array} \\
\end{array}$ & B. Ma & ture \\
\hline $\begin{array}{c}6 \\
\begin{array}{c}\text { property and real } \\
\text { estate }\end{array}\end{array}$ & $\begin{array}{c}7 \\
\text { infrastructure, } \\
\text { utilities, and } \\
\text { transportation }\end{array}$ & $\begin{array}{c}8 \\
\text { finance }\end{array}$ & $\begin{array}{c}9 \\
\text { trade, services, } \\
\text { and investment }\end{array}$ & C. Services \\
\hline
\end{tabular}

Figure 3: Industry Classification in Indonesian Stock Exchange (Sembiring, 2012)

From nine sectors, three parts were grouped, namely raw material producers, manufacturing, and services. The raw material production sector is the foundation of the other two sectors. Meanwhile, the services sector is a supporting sector that supports the manufacturing sector. Based on the relationship of this supply chain, when the raw material producer sector is exposed to ESG risk, then the entire supply chain will be affected.

This research focuses on the raw material production sector, namely agriculture, and mining. This is caused by two sectors that will be directly affected by ESG so that the risks can be identified directly and not the indirect risks that are more difficult to identify and measure. By combining the Porter framework with the value drivers of each Porter Five Forces, this study seeks to find out what are the risks that can affect the value of a company, especially related to investment decisions based on ESG value. 
Further in Table 2 is explained the operational definition of each of the Porter forces that led to the creation of the Firm Value.

Table 2. Operational Definitions of Firm Value

\begin{tabular}{|c|c|c|}
\hline Firm Value & Source & Definition \\
\hline $\begin{array}{l}\text { Bargaining } \\
\text { Power of } \\
\text { Suppliers }\end{array}$ & Li (2019) & $\begin{array}{l}\text { The strength of the supplier is when the supplier can negotiate a contract } \\
\text { that is more favorable for him. }\end{array}$ \\
\hline $\begin{array}{l}\text { Rivalry Among } \\
\text { Existing } \\
\text { Competitors }\end{array}$ & $\begin{array}{l}\text { Kilduff } \\
\text { (2019) }\end{array}$ & $\begin{array}{l}\text { Rivalry is a relational relationship between a company and its competitors } \\
\text { that is formed from the similarity of products that have occurred } \\
\text { repeatedly and give the consequences in the form of real bets due to the } \\
\text { competition. }\end{array}$ \\
\hline $\begin{array}{l}\text { The Threat of } \\
\text { Substitute } \\
\text { Products }\end{array}$ & $\begin{array}{l}\text { Bade et al } \\
(2019)\end{array}$ & $\begin{array}{l}\text { Substitute goods are goods that have more or less the same function so that } \\
\text { the goods can replace the replaced goods without sacrificing the function } \\
\text { of the replaced goods. }\end{array}$ \\
\hline $\begin{array}{l}\text { Bargaining } \\
\text { Power of } \\
\text { Buyers }\end{array}$ & $\begin{array}{l}\text { Omillo } \\
(2019)\end{array}$ & $\begin{array}{l}\text { The strength of the buyer means the ability of the buyer to bid on the price } \\
\text { offered by the seller and force the seller to lower the price, improve the } \\
\text { quality and make terms and agreements that benefit the buyer. }\end{array}$ \\
\hline $\begin{array}{l}\text { The threat of } \\
\text { New Entrants }\end{array}$ & $\begin{array}{l}\text { Porter } \\
(2008)\end{array}$ & $\begin{array}{l}\text { The threat from new players is when a new player brings a new production } \\
\text { capacity and to gain market share puts pressure on the selling price. }\end{array}$ \\
\hline
\end{tabular}

Source: Collected by Author, 2020

\section{ANALYSIS AND DISCUSSION}

The raw material production sector on the Indonesian Stock Exchange consists of two main sectors, namely agriculture, and mining. Although these two sectors both produce raw materials both have different properties.

Devi (2020) examines the effect of companies' risks engaged in the agricultural industry and firm value. Although agricultural companies are based on agricultural commodities' life cycle, in business, agricultural companies also have risks that arise from the business cycle, especially from corporate consumers. Utami (2020) states that agricultural companies face uncertainty in selling their manufactured goods. The source of this uncertainty is because agricultural companies face external factors in their production, namely factors such as weather factors. Weather factors will affect crop yields, which will affect the number of bids owned by the company. The agricultural sector is a sector that can be constantly renewed but the level of innovation depends on how the company manages the environment. Hendayana (2020) sees the agricultural sector as limited to managing risks faced by the agricultural industry and an opportunity to increase value through innovation. Harsanto (2020) exemplifies the application of technology. In this case, information technology, namely the internet of things, can increase automation in the agricultural sector's machinery management, whose ultimate goal is to increase production output in the agricultural sector. Meanwhile, the mining sector cannot be renewed and if mining is done irresponsibly, the losses will be incurred after the mining company leaves the mining area. Solekhah and Effendi (2020) state the importance of governance in ensuring the management of limited natural resources. Maharani (2021) stated that in the process of seeking profits from mining companies, environmental factors need to be considered which can be called green accounting. 
Table 3. Value Driver and ESG Risks that Affect Firm Value in Agribusiness

\begin{tabular}{ll}
\hline Firm Value & \multicolumn{2}{c}{ Value Driver } \\
\hline Bargaining & To be efficient the \\
Power of & plantation industry \\
Suppliers & $\begin{array}{l}\text { depends on the mastery of } \\
\text { raw materials. }\end{array}$
\end{tabular}

ESG Risks

Although the company controls most of the raw materials, there are risks associated with the planting process that as the risk of land processing for plantation companies. Such risks include water availability and land clearing in oil palm. Opening up land by burning is an efficient thing. While an environmentally friendly way to open land requires expensive costs and will not provide a short-term return (Landes, 2008).

\begin{tabular}{llr}
\hline Rivalry Among & Companies in the \\
Existing & plantation industry \\
Competitors & compete with each other to \\
& increase & production \\
& capacity. Increased \\
& production capacity can be \\
& done by increasing the \\
& land.
\end{tabular}

Agricultural companies depend on the land. Increasing yields per square meter can be done by investing in better technology and seedlings but in the end, the amount of land managed determines the total yield that can be generated by the company. This will create competition between companies in acquiring land. The consequences of long-term land grabs will incur additional costs that encourage enterprises to convert land that is not allocated for agriculture and plantations such as land for forests. Deforestation will pose an environmental risk (Cubbage, 2007).

The Threat of Agricultural commodities Substitute are diverse commodities in Products which one product can be replaced by another even though it does not have the same function.

Agricultural commodities are diverse and standardization is challenging. For example, coffee beans are very diverse in quality and taste. Improper management will damage the taste of the product. The same goes for oil palm ore whose quality and the quantity depend on the soil and the planting process. On the other hand, consumers want quality products that have standards.

Bargaining Buyers of products from Power of plantation companies Buyers consist of two main segments, namely retail buyers and corporate buyers. Corporate buyers have strong bargaining power especially because of their great purchasing power.

\begin{tabular}{lll}
\hline The threat of & Agricultural companies & Although building a company in the field of agriculture \\
New Entrants & require large investments & requires high costs but due to a large number of \\
& not only in the acquisition & commodities in the field of agriculture then consumers can \\
& of land and supply chains & switch to products that although not the same can provide \\
& but also in the a similar function. An example is when consumers feel \\
development of research & coconut oil is not environmentally friendly then consumers \\
and technology for seed & can switch to soybean oil. In taste and quality, these two \\
development. This will & products are oils that give a different taste, quality, and \\
cause a high barrier to price but not all consumers have complete knowledge of & entry into the plantation the product and consider soybean oil as a substitution.
\end{tabular}

Source: Authors' findings, 2020

Table 1 shows how ESG risk can affect each value driver variable in the Porter framework. The greater the ESG factor that affects the value driver, the more value the driver will be volatile and will affect the competitiveness of the company as a whole. 
Further Table 2 will look at the ESG risks to individual value drivers in the mining industry.

Table 4. Value Driver and ESG Risks that Affect Firm Value in Mining Industries

\begin{tabular}{|c|c|}
\hline Firm Value & Value Driver \\
\hline $\begin{array}{l}\text { Bargaining } \\
\text { Power of } \\
\text { Suppliers }\end{array}$ & $\begin{array}{l}\text { Mining companies and oil } \\
\text { companies obtain drilling } \\
\text { rights from the government. } \\
\text { The value of a mining } \\
\text { company is how much } \\
\text { revenue it can extract from the } \\
\text { belly of the earth. }\end{array}$ \\
\hline $\begin{array}{l}\text { Rivalry } \\
\text { Among } \\
\text { Existing } \\
\text { Competitors }\end{array}$ & $\begin{array}{l}\text { Mining companies today are } \\
\text { big companies that dominate } \\
\text { the market. In addition to } \\
\text { privately-owned companies, } \\
\text { large and numerous } \\
\text { competitors are state-owned } \\
\text { companies. }\end{array}$ \\
\hline
\end{tabular}
ESG Risks

The government will ask for requirements to protect the environment especially after the mining and mining process is abandoned. Because the mining company is an extraction company, once it is abandoned, there will be no economic value left for the local community. If the mining company is considered by the government not to comply with environmental regulations then the government has the right not to extend the employment contract. This is a big risk for mining and oil companies whose operations depend on what can be extracted.

State companies have the support of the state and in this case, can be a competitor for private companies because the state will tend to develop its business entities. One of the alternatives that are often taken is to do a joint venture. The challenge in managing a joint venture business is the difference in value between the two companies. These value differences can have significant consequences when companies operate in developing countries that do not yet have clear environmental regulations and policies (Esteves, 2008).

The Threat Mining companies have a of Substitute wide variety of products from Products one type of commodity. This product diversification presents challenges in competition especially when there are competitors who specialize in one type of product.

\begin{tabular}{ll}
\hline Bargaining & Consumers of mining \\
Power of & companies are mostly \\
Buyers & corporations. But the price of \\
& this mining commodity is \\
& greatly influenced by the \\
& demand and supply in the \\
& world. When one of the big \\
& manufacturers with a high \\
& number of products floods the \\
& market then the price of \\
& commodities will fall. \\
\hline The threat & Mining companies are well- \\
of New & established companies and \\
Entrants & require large costs to enter. \\
& The high barrier to entry \\
& causes fewer competitors to \\
& enter the industry.
\end{tabular}

Mining companies are prone to new technologies, especially renewable technologies. Renewable technology can create demand or at least reduce the need for mining products. Another thing is the emergence of more economical technology that allows consumers to choose the product. One example is solar panels that reduce the need for electricity because retail consumers can store solar energy to meet their daily needs. This means that when electricity consumption then power generation companies will have less demand. The consequence is that power plants will buy less raw materials from mining companies (Foo et al, 2018).

The end consumers of energy companies are retail consumers. And the sentiments of retail companies will affect the demand for some form of energy. One of them is the trend of electricity consumption in Northern Europe will increase the demand for products with alternative energy. One of them is the high demand for electric cars in Northern Europe. With the shift of consumers to electric cars then manufacturers will start switching to electric cars. This will further reduce the demand for fuel oil.

Although the mining industry is an established industry, technological change can have a disruptive effect. The effect of this disruption is on new technologies such as fracking in the oil industry that allow individual entrepreneurs to extract oil as is the case in the United States. Economically these individual companies will not be able to compete with the giant oil companies. However, the large number of small companies will reduce the potential of land that can be acquired by large companies. Thus giant oil companies will gain competence in gaining access to raw materials due to this competitive effect. 
The two tables above compare how the two industries have driver value. Each has a risk against ESG factors. The presence of ESG factors will affect each variable. If each variable in the value driver is weak then the value of the company as a whole is weak. Companies need to pay attention to the ESG factor and manage it especially for the sustainability of the company.

\section{E. CONCLUSIONS}

Porter's framework is a framework that has been commonly used to assess the competitive advantage of a company and an industry. By combining Porter's framework with the values of Environmental, Social, and Governance, this study shows that the value of ESG will affect the company's value. From the application of Porter's framework in an industry, the risk factors that affect an industry will be seen.

For example, the agricultural industry, although it is a natural resource that can be continuously renewed, its sustainability can be reduced. The decline in agricultural production can be caused by decreased soil fertility, changes in rainfall due to damage factors. In the end, the number of commodities that the agricultural industry can produce will decrease so that the value of the company will decrease because there are fewer commodities that the company can sell. Meanwhile, mining companies that, although not dependent on environmental factors, such as the agricultural industry, are still affected by ESG factors' risks, mainly because of mining industry operations.

This study shows that ESG factors affect the competitive advantage of companies and industries. When a company in an industry ignores the value of ESG, the company will experience a decrease in its competitiveness. Meanwhile, if the industry does not pay attention to the ESG factor, the industry will decline compared to other industries that pay attention to the ESG factor. Thus, company managers can benefit from this study to manage the company dimensions affected by ESG factors to optimize firm value. Another practical benefit that management can get by applying ESG values is broadening the company's investor base. The company will convince investors who only want to invest in companies that have a high social responsibility value to invest.

\section{REFERENCES}

Bohnert, A., Gatzert, N., Hoyt, R. E., \& Lechner, P. (2019). The drivers and value of enterprise risk management: evidence from ERM ratings. The European Journal of Finance, 25(3), 234-255.

Bade, R., \& Parkin, M. (2019). Essential foundations of economics. Pearson Education.

Briand, R., Urwin, R., \& Chia, C. P. (2011). Integrating ESG into the investment process. MSCI ESG Research, New York, NY, available at: www. msci. com/resources/research_papers/integrating_esg_into_the_investment_process_2. html (accessed 20 April 2013).

Cubbage, F., Mac Donagh, P., Júnior, J. S., Rubilar, R., Donoso, P., Ferreira, A., ... \& Siry, J. (2007). Timber investment returns for selected plantations and native forests in South America and the Southern United States. New Forests, 33(3), 237-255.

Damodaran, A. (2016). Damodaran on valuation: security analysis for investment and corporate finance (Vol. 324). John Wiley \& Sons. 
Dawson, A. (2020, January 09). Our push to WTO helps protect Indonesia's vital log export ban from threat of trade tariffs. Retrieved August 23, 2020, from https://eia-international.org/blog/our-push-to-wto-helps-protect-indonesias-vitallog-export-ban-from-threat-of-trade-tariffs/

Devi, S. K. (2020). Pengaruh Struktur Modal dan Risiko Perusahaan terhadap Nilai Perusahaan (Studi Kasus pada Perusahaan Pertanian yang Terdaftar di Bursa Efek Indonesia Periode 2009-2018) (Doctoral dissertation, Universitas Negeri Semarang).

Esteves, A. M. (2008). Mining and social development: Refocusing community investment using multi-criteria decision analysis. Resources Policy, 33(1), 39-47.

Foo, N., Bloch, H., \& Salim, R. (2018). The optimization rule for investment in mining projects. Resources Policy, 55, 123-132.

Freudenreich, B., Lüdeke-Freund, F., \& Schaltegger, S. (2020). A stakeholder theory perspective on business models: Value creation for sustainability. Journal of Business Ethics, 166(1), 3-18.

Giovanni, A., Utami, D. W., Astuti, U. D., \& Fania, F. (2021). Konflik Keagenan dalam Perspektif Keuangan Keperilakuan.JAF-Journal of Accounting and Finance, 5(1), 1-10.

Harsanto, B. (2020). Inovasi Internet of Things pada Sektor Pertanian: Pendekatan Analisis Scientometrics. Informatika Pertanian, 29(2), 111-122.

Hendayana, R. (2020). Membangun Sistem Diseminasi di Era Disrupsi: Peluang dan Tantangan Mempercepat Hilirisasi Inovasi Pertanian. Global Media Publikasi.

Holland, J. (2011). A conceptual framework for changes in fund management and accountability relative to ESG issues. Journal of Sustainable Finance \& Investment, 1(2), 159-177.

Kilduff, G. J. (2019). Interfirm relational rivalry: Implications for competitive strategy. Academy of Management Review, 44(4), 775-799.

Landes, M. R. (2008). The environment for agricultural and agribusiness investment in India (No. 1476-2016-121004).

Li, T. (2019). Escaping Bear Hugs: A New Venture's Network Building and the Effects on Its Bargaining Power (Doctoral dissertation).

Maharani, P. (2021). Pengaruh Green Accounting pada Nilai Perusahaan Sektor Pertambangan. Edumaspul: Jurnal Pendidikan, 5(1), 220-231.

Omillo, F. O. (2019). Estimating the effect of buyers' bargaining power on Kenyan small food manufacturers' income. Independent Journal of Management \& Production, 10(2), 548-573.

Palepu, K. G., \& Healy, P. M. (2013). Business analysis and valuation: Using financial statements, text and cases.

Penman, S. (2016). Valuation: accounting for risk and the expected return. Abacus, 52(1), 106-130.

Porter, M. E. (2008). The five competitive forces that shape strategy. Harvard business review, 86(1), 25-40.

Schramade, W. (2016). Integrating ESG into valuation models and investment decisions: the value-driver adjustment approach. Journal of Sustainable Finance \& Investment, 6(2), 95-111.

Sembiring, S. A. (2012). Pengaruh Klasifikasi Industri dan Ukuran Perusahaan terhadap Risiko Bisnis pada Perusahaan Manufaktur Yang Terdaftar di Bursa Efek Indonesia (BEI) (Doctoral dissertation, Universitas Negeri Padang). 
Solekhah, M. W., \& Efendi, D. (2020). Pengaruh Good Corporate Governance (GCG) terhadap Profitabilitas Perusahaan Sektor Pertambangan. Jurnal Ilmu dan Riset Akuntansi (JIRA), 9(6).

Subramanyam, K. R. (2014). Financial statement analysis. McGraw Hill Education.

Tahu, G. P. (2019). Pengaruh Kinerja Lingkungan dan Pengungkapan Lingkungan Terhadap Kinerja Keuangan (Studi Pada Perusahaan Manufaktur yang Terdaftar di BEI). Jurnal Ekonomi dan Pariwisata, 14(1).

Taleb, N. N., \& Blyth, M. (2011). The black swan of Cairo: How suppressing volatility makes the world less predictable and more dangerous. Foreign Affairs, 33-39.

Tandelilin, E. (2010). Portofolio dan Investasi: Teori dan aplikasi. Kanisius.

Yeomans, L. (2017). Qualitative methods in business research. 